\title{
The Results of Mining and Geometric Analysis in Open Pit Mining of Promising Kuzbass Coal Deposits with Block System
}

\author{
Alexei Selyukov ${ }^{1, *}$, Andrey Gerasimov ${ }^{1}$, and Valery Grishin ${ }^{2}$ \\ ${ }^{1}$ T.F. Gorbachev Kuzbass State Technical University, Department of open pit mining, 650000 \\ Kemerovo, 28 Vesennya st., Russian Federation \\ ${ }^{2}$ Ministry of Energy of the Russian Federation, 107996 GSP-6, Moscow, Russia
}

\begin{abstract}
Currently, in developing the most inclined and steep coal deposits in the Central and Northern Kuzbass (Western Siberia, Russia), the deeping longitudinal open pit mining method is used with overburden rock moved to external dumps using transport technology. One of the ways to reduce the rate of land withdrawal while reducing development costs by shortening the distance of overburden movement is to use block lateral mining method with overburden storage in the worked out space. The paper emphasizes that well-known technological solutions consider quarry fields untouched by mining, or in the process of exploitation, so the block mining procedure is using fragmentally along with moving overburden by dump trucks. Internal dumping, as an element of land preservation, has not been generally considered to date. This is a deterrent to the implementation of resource-saving mining technologies, both in design and mining practice.
\end{abstract}

\section{Introduction}

This article discusses the results of a study of coal reserves within the boundaries of the fields of open pit mines of Kuzbass (Western Siberia, Russia), suitable for block extraction. It has been established that about 350 seams of coal of various types and capacities are concentrated in the coal-bearing stratum of Kuzbass [1]. They are unevenly distributed, for example, the Tarbaganskaya formation includes 19 layers, while the Balakhonskaya and Kalchuginskaya formations count up to 237. The highest thickness of the coal formation in Kuzbass is 370 $\mathrm{m}$ [2]. As a rule, seams with thickness from 1.3 to $4 \mathrm{~m}$ prevail, but in some segments, this value reaches 9, 15, and sometimes $20 \mathrm{~m}$ [3]. The bulk of the coal reserves in Kuzbass are in areas with intensive open pit mining, such as Leninsky and Erunakovsky ones - about 36 billion tons of coal. In the Tomsk-Usinsk and Prokopyevsk-Kiselyov segments, 14 billion tons are located, in Kondom and Mrass -8 billion tons, in Kemerovo and Baidaev - 6.6 billion tons [4]. Today, industrial enterprises have developed $16 \%$ of all reserves. Therefore, the analysis of the prospects for using reserves in open pit coal mining is highly relevant.

The performance indicators of the Kuzbass coal deposits were the initial base of the study, since they allow considering all groups of deposits in real mining and geological conditions.

${ }^{*}$ Corresponding author: sav.ormpi@,kuzstu.ru 
Coal deposits of Kuzbass are characterized by stratum bedding of seams with their number in formations from 6 to 65 , depending on the belonging to productive sediments of the Balakhonskaya and Kolchuginskaya series [5]. Most of the deposits are located in zones of significant tectonic disturbances, which determined a large spread in the angles of incidence of reservoirs. Coal seams in the basin to a depth of $1800 \mathrm{~m}$ are about 725 billion tons, to a depth of $600 \mathrm{~m}$ - about 110.8 billion tons, including 22.4 billion tons - coking coal [6].

\section{Materials and Methods}

With the proposed longitudinal mining method, the quarry field is divided along the length into separate sections (blocks), the mining of which to the final depth is carried out sequentially, from one block to another, while mining of all blocks is carried out according to usual longitudinal deeping method [7]. The first block is developed with the removal of overburden into an external dump. After its development to a final depth, an initial capacity is formed for the further formation of the internal dumps for second block. Then the workedout space of the second block is filled with the overburden of the third, third of the fourth, etc. (Fig. 1).

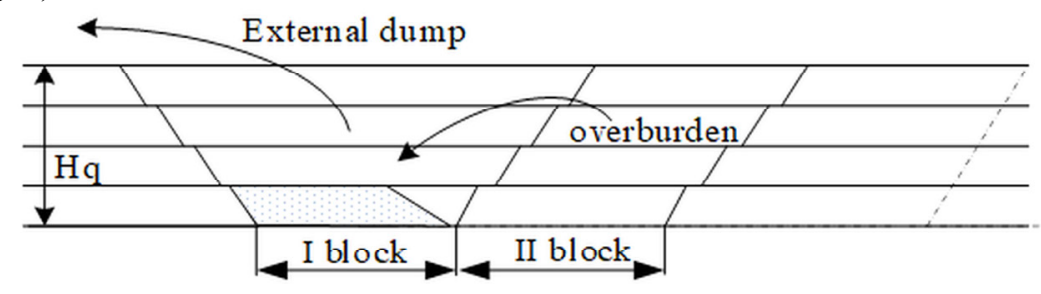

Fig. 1. Longitudinal-and-block mining method for the development of coal deposits (Hq - the depth of the quarry, $\mathrm{m}$ ).

Thus, the cargo flows of overburden and mineral of the first block are sent outside the quarry field. The development of the second and subsequent blocks is accompanied by cargo flows of minerals sent outside the quarry field and cargo flows of overburden sent to the worked out space of the previous block.

The advantages of this technology include a significant reduction in the area occupied by external dumps, as well as the volumes of overburden taken out to the external dump depend only on the overburden volume of the first block. In addition, the advantages include a decrease in the length of transportation of overburden and the possibility of mining all the seams of the formation from the side of the seams' roof, which allows reducing the loss of coal in the bowels.

The disadvantages of the block mining method include the rigid relationship between the face and dump zones, as well as the unevenness of the mining regime, and hence the uneven formation of overburden cargo flows in each block, which is due to both the specificity of the longitudinal development system and the order of mining blocks. Moreover, if each subsequent block is worked out at the end of the work in the previous one, then fluctuations in the volume of cargo transportation can occur not only in overburden, but also in coal, which also refers to disadvantages. To avoid this and maintain a constant level of coal extraction, it is necessary to begin stripping in the second block in parallel with the completion of the first one with the removal of overburden also to external dumps [8-9]. All subsequent volumes are located in the internal dumps, but when finalizing each block, advanced stripping operations in the next block should be carried out.

Table 1 shows the reserves suitable for development by block mining method, to a depth actually achievable by open pit mining. 
Table 1. Reserves suitable for excavation by block mining method in Kuzbass.

\begin{tabular}{|c|c|c|c|c|c|c|c|c|}
\hline \multirow{2}{*}{$\begin{array}{c}\text { Seam dip } \\
\text { angle, } \\
\text { degrees }\end{array}$} & \multirow{2}{*}{$\begin{array}{c}\text { Total coal } \\
\text { reserves, } \\
\text { million } \\
\text { tons }\end{array}$} & \multicolumn{7}{|c|}{ Seam thickness, m } \\
\hline & & $\begin{array}{l}1.00- \\
1.20\end{array}$ & $\begin{array}{l}1.21- \\
1.80\end{array}$ & $\begin{array}{l}1.81- \\
2.50\end{array}$ & $\begin{array}{l}2.51- \\
3.50\end{array}$ & $\begin{array}{c}3.51- \\
4.50\end{array}$ & $\begin{array}{c}4.51- \\
6.50\end{array}$ & $\begin{array}{c}\text { Over } \\
6.5\end{array}$ \\
\hline $19-24$ & 158.5 & 0.15 & 1.23 & 8.49 & 8.32 & 8,35 & 32,52 & 99,28 \\
\hline \multirow[t]{2}{*}{$25-35$} & 104.5 & - & 1.53 & 1.84 & 6.33 & 3.60 & 44.11 & 47.06 \\
\hline & 263.0 & 0.15 & 2.76 & 10.33 & 14.65 & 11.95 & 76.63 & 146.34 \\
\hline $36-45$ & 108.4 & 0.43 & 1.85 & 5.04 & 10.17 & 8.82 & 38.88 & 43.19 \\
\hline \multirow{2}{*}{$46-90$} & 1011.7 & 9.14 & 19.72 & 63.33 & 60.33 & 75.93 & 146.04 & 637.11 \\
\hline & 1120.1 & 9.57 & 21.57 & 68.37 & 70.50 & 84.75 & 184.92 & 680.30 \\
\hline Grand total & 1383.1 & 9.72 & 24.33 & 78.70 & 85.15 & 96.70 & 261.55 & 824.64 \\
\hline$\%$ & 100 & 0.70 & 1.76 & 5.70 & 6.15 & 7.00 & 18.9 & 59.79 \\
\hline $\begin{array}{l}\text { Per cent by } \\
\text { groups }\end{array}$ & 100 & \multicolumn{5}{|c|}{21.3} & \multicolumn{2}{|c|}{$\frac{1}{78.7}$} \\
\hline
\end{tabular}

The main coal reserves (about 80\%) are concentrated in medium and thick seams. Therefore, when applying such systems, difficulties will arise with the development of thin and extra thin seams $(1-4.5 \mathrm{~m})$.

\section{Results and Discussion}

Currently, the development of these reserves in Kuzbass is carried out exclusively using longitudinal single and double-sided mining method. The depth of mining on individual existing open pits or sections is in the range from $60-80 \mathrm{~m}$ to $180-210 \mathrm{~m}$ or more.

For these open pits, the issue of using block mining method requires independent research, since the transition from the longitudinal direction of the development of the lateral one is associated with overcoming a number of technical, technological and economic problems.

Therefore, in this study, the main focus is on areas of promising coal fields with seam's dip angles from inclined to steep, where block mining method can be used, including using direct dumping (table 2).

It should be noted that in addition to the large promising areas indicated in table 2 in the coal basin, there is a significant number of sites with smaller reserves.

Table 2. Characterization of reserves in the areas of prospective coal deposits of the Kuznetsk basin to a depth of $600 \mathrm{~m}$.

\begin{tabular}{|c|c|c|c|c|c|c|}
\hline \multirow[t]{2}{*}{ No. } & \multirow[t]{2}{*}{$\begin{array}{l}\text { The name of the } \\
\text { prospective site }\end{array}$} & \multirow{2}{*}{$\begin{array}{c}\text { Coal } \\
\text { reserves, } \\
\text { million } \\
\text { tons }\end{array}$} & \multirow{2}{*}{$\begin{array}{c}\text { Coal } \\
\text { seams } \\
\text { number }\end{array}$} & \multicolumn{2}{|c|}{$\begin{array}{l}\text { Total seam } \\
\text { thickness, } M\end{array}$} & \multirow{2}{*}{$\begin{array}{c}\text { Seam dip } \\
\text { angle, } \\
\text { degrees }\end{array}$} \\
\hline & & & & from & to & \\
\hline 1 & Alardinsky 1-2 & 182.5 & 3 & 18.8 & 33.5 & $10-25$ \\
\hline 2 & Alardinsky 3 & 55.3 & 2 & 6.9 & 13.4 & 20 \\
\hline 3 & Apanasovsky & 22.4 & 7 & 5.27 & 43.04 & $13-51$ \\
\hline 4 & Inskoy & 469.8 & 14 & 85.57 & 187.91 & $5-50$ \\
\hline 5 & Karakansky 1-2 & 564.6 & 20 & 120.6 & 245.4 & $15-70$ \\
\hline 6 & Karakansky 3 & 173.0 & 20 & 120.6 & 245.4 & $15-70$ \\
\hline 7 & Караканский 4 & 192.0 & 20 & 120.6 & 245.4 & $15-70$ \\
\hline 8 & Karakansky Eastern & 480.0 & 20 & 120.6 & 245.4 & $15-70$ \\
\hline 9 & Kureinsky 1 & 80.0 & 6 & 12.2 & 49.0 & $8-25$ \\
\hline 10 & Mikhailovsky & 35.0 & 2 & 2.2 & 13.8 & $20-70$ \\
\hline 11 & Raspadsky & 49.3 & 2 & 14.9 & 22.9 & $10-25$ \\
\hline 12 & Siberian 3 & 120.0 & 6 & 24.0 & 47.0 & $8-25$ \\
\hline 13 & Teshsky 1 & 360.0 & 4 & 16.35 & 73.5 & $25-35$ \\
\hline
\end{tabular}




\begin{tabular}{|l|c|c|c|c|c|c|}
\hline 14 & Taldinsky North & 130.0 & 16 & 32.0 & 170.0 & $40-60$ \\
\hline 15 & Uregolsky 1 & 189.1 & 4 & 19.05 & 25.82 & $7-30$ \\
\hline 16 & Uregolsky 2 & 90.0 & 6 & 11.88 & 56.0 & $8-25$ \\
\hline 17 & Uregolsky 3 & 90.0 & 6 & 12.0 & 57.0 & $8-25$ \\
\hline 18 & Urope 1 & 120.1 & 12 & 52.19 & 95.94 & $5-50$ \\
\hline 19 & Urope 2 & 268.9 & 12 & 66.1 & 155.98 & $5-50$ \\
\hline 20 & Urope 3 & 350.0 & 18 & 96.84 & 221.35 & $5-50$ \\
\hline 21 & Urope Nothern & 190.0 & 11 & 52.19 & 95.94 & $5-50$ \\
\hline 22 & Chernokaltansky 1-2 & 110.0 & 4 & 18.33 & 32.8 & $25-35$ \\
\hline 23 & Chernokaltansky 3-4 & 258.7 & 4 & 17.10 & 32.32 & $25-35$ \\
\hline
\end{tabular}

For selection the type of field suitable for development, justification of the area and the boundaries of its application, it is also necessary to take into account a number of factors: the shape of the deposit in the plan and its parameters along strike and cross strike; surface topography and the presence of loose deposits (sedimenst); the structure of coal-bearing formations; consistency of bedding, disturbance of the coal field; strength properties of overbirden and coal; coal seams quality.

The shape and length of coal deposit determine the technical feasibility of using the block mining order, as well as the size of the quarry field, the scale of production and efficiency.

The surface relief can determine the technical feasibility of using lateral mining method, affect the depth of mining, the average stripping ratio and overburden removal method.

The thickness of loose deposits can determine the economic feasibility of using the development system, the volume of mining and construction works, the scale of investments and the average stripping ratio.

The dip angle determines the design and parameters of technological schemes, the type and models of mining and loading and transport equipment.

The structure of coal-bearing formations determines the order of their mining:

- all formations of the formation are worked out within the same quarry field;

- only individual seams or local groups of seams are mined within the same quarry field;

- separate groups of seams are mined by independent quarry fields.

The nature of the concentration of coal seams in the formation determines the design depth of mining operations, the technological features of mining rock-and-coal stopes, and determines the options for preparing the seams for excavation.

The sustainability or variability of the dip angles within the excavation stope by its height determines the location of the cutting niches for subsequent excavation and organization of works on the horizon, determine the size and type of excavation equipment, and also affect the decision-making on the height of the bench.

Disturbance of coal seams determines the complexity of the blasting, overburden and coal excavation in faulting zones, as well as the amount of coal loss.

The strength properties of overburden and coal determine the method and parameters of the process of preparing them for excavation, as well as the type of excavation and loading equipment. The qualitative characteristic of the coal in the seam sets the degree of efficiency of the mining technology for the whole deposit for the entire field.

For a qualitative and quantitative assessment of the bedding conditions of the formation based on the listed factors, based on the analysis of the vast material, we selected the characteristic plans for the outbursts of sediments, as well as geological sections and profiles for promising and developing deposits of Kuzbass.

In accordance with the classification of the types of deposits in Kuzbass as a coal basin, their shapes in plan have the following forms: rounded $(\mathrm{B}<\mathrm{L}<1.4 \mathrm{~B}$, where $\mathrm{B}$ is the width of the deposit on the surface, L is its length), elongated $(1.4 \mathrm{~B}<\mathrm{L}<4 \mathrm{~B})$, and stretched $(4 \mathrm{~B}<\mathrm{L}<40 \mathrm{~V})$. Table 3 shows the shape and parameters of deposits in several promising areas. 
In Kuzbass, open pit fields are predominantly elongated with a strike length of $4 \mathrm{~km}$ to 9.2 $\mathrm{km}$. There are fewer areas of round and elongated shape.

The parameters of the segments allow using of a block mining method, although with a round shape of the deposit, it is necessary to conduct checking for the placement of the first stage quarry in the contours of the deposit.

Table 3. The form and parameters of coal deposits in the plan.

\begin{tabular}{|c|c|c|c|c|}
\hline Segment & $\begin{array}{c}\text { Parameters L } \\
\text { and B, km }\end{array}$ & $\begin{array}{c}\text { Rounded } \\
\mathbf{B}<\mathbf{L}<\mathbf{1 , 4} \mathbf{B}\end{array}$ & $\begin{array}{c}\text { Elongated } \\
\mathbf{1 , 4 B}<\mathbf{L}<\mathbf{4 B}\end{array}$ & $\begin{array}{c}\text { Stretched } \\
\mathbf{4 B}<\mathbf{L}<\mathbf{4 0 B}\end{array}$ \\
\hline Inskoy & $\mathrm{L}=9.2 ; \mathrm{B}=3.5$ & - & $4.9<9.2 \leq 14$ & - \\
\hline Karakansky 1-2 & $\mathrm{L}=6 ; \mathrm{B}=4.7$ & $4.7<6<6.6$ & - & - \\
\hline Karakansky Eastern & $\begin{array}{c}\mathrm{L}=8 ; \mathrm{B}=1.4- \\
4.5(\mathrm{~B} a v=2.95)\end{array}$ & - & $4.13<8 \leq 11.8$ & - \\
\hline Karakansky Southern & $\mathrm{L}=4.9 ; \mathrm{B}=4$ & $4<4.9 \leq 5.6$ & - & - \\
\hline Taldinsky North & $\mathrm{L}=2.8 ; \mathrm{B}=2$ & $2<2.8 \leq 2.8$ & - & - \\
\hline Urope 1 & $\mathrm{L}=4 ; \mathrm{B}=1.8$ & - & $2.5<4 \leq 7.2$ & - \\
\hline Urope 2 & $\mathrm{L}=4.6 ; \mathrm{B}=2.8$ & - & $3.9<4.6 \leq 11.2$ & - \\
\hline Urope 3 & $\mathrm{L}=7 ; \mathrm{B}=2.1$ & - & $2.9<7 \leq 8.4$ & - \\
\hline Urope Nothern & $\mathrm{L}=7 ; \mathrm{B}=2.1$ & - & $2.9<7 \leq 8.4$ & $1.36<2<13.6$ \\
\hline Korchakolsky & $\mathrm{L}=2.0 ; \mathrm{B}=0.34$ & - & - & \\
\hline
\end{tabular}

To analyze the surface topography of coal deposits and the thickness of sediments, geological sections were used based on the materials of the Kuzbassuglerazvedka Company. Four types of surface topography were identified: plain, sloping, bumpy-valley (hilly) and hilly-mountainous.

When analyzing the structure of the coal-bearing stratum, the following concepts were accepted:

- the working seam is a seam whose normal thickness $(\mathrm{m})$ exceeds $5 \mathrm{~m}$;

- the seam of associated excavation is a seam whose normal thickness is less than $5 \mathrm{~m}$;

- the single seam is a working seam developed independently;

- the group of seams - the seams to be developed; the group may include only working strata and strata of associated mining, onlythe strata of associated mining.

Of great importance for the mining method is the distance between the seams of the formation (the thickness of interstitial rocks), which at certain values can determine the economic feasibility of using this method. The distribution density of the seams in the formation can be determined as their concentration.

The concentration of the seams in the formation can be estimated by the qualitative characteristics: concentrated and dispersed. A quantitative assessment of the border between these groups is considered as depending on the economic factor - the boundary stripping ratio.

The determination of the boundary between groups can be carried out based on the individual examination of the system "the seam - interlayer above its roof". For this method, a preliminary assessment of the economic feasibility of mining a certain seam by the value of the average stripping ratio is given.

For the length of one meter of the deposit, the average stripping ratio $\left(\mathrm{Kav}, \mathrm{m}^{3} / \mathrm{t}\right)$ is:

$$
K_{a v}=\frac{H_{l} \times M \times \sin a}{H_{l} \times m \times \sin a \times p_{c}}=\frac{M}{m \times p_{c}}
$$

where: $H_{l}$ - excavation layer height, m;

$M$ - normal interbed's thickness, m;

$m$ - normal seam's thickness, m; 
$a$ - seam dip angle, degrees;

$p_{c}-$ coal density, $\mathrm{t} / \mathrm{m}^{3}$.

Currently, depending on the specific geological conditions in the Kuzbass, an economically feasible stripping ratio $\left(K_{e f}\right)$ is from 5 to $8 \mathrm{~m}^{3} / \mathrm{t}$.

Then, replacing the average stripping ratio in equation (1) by the boundary one, we obtain the limiting condition of the practicability of mining the coal seams formation:

$$
M_{\text {max }}^{e f}=K_{e f} \times m \times p_{c}
$$

where: $M^{e f}{ }_{\max }$ - the maximum allowable value of the interbed thickness at which the development of the formation is economically feasible, $\mathrm{m}$.

We believe that under the condition $M<M^{e f}{ }_{\max }$ (where $M$ is the thickness of the interbed above the analyzed formation, $\mathrm{m}$ ), the formation is concentrated in relation to the overlying formation. If $M>M^{e f}$ max, than the formation is dispersed with respect to the overlying formation.

For the analysis of formations, the maximum values of the interbeds' thickness were calculated, within which the strata are considered concentrated (Table 4).

Table 4. The maximum interbeds' thickness values determining concentration of two seams.

\begin{tabular}{|c|c|c|c|c|c|c|c|c|c|}
\hline \multirow{2}{*}{$\begin{array}{c}\text { Seam } \\
\text { thickness, } \\
\text { m }\end{array}$} & \multicolumn{4}{|c|}{$\begin{array}{l}\text { Boundary stripping ratio, } \\
\mathrm{m}^{3 / t}\end{array}$} & \multirow[t]{2}{*}{$\begin{array}{c}\text { Seam } \\
\text { thickness, } m\end{array}$} & \multicolumn{4}{|c|}{$\begin{array}{c}\text { Boundary stripping ratio, } \\
\mathbf{m}^{3} / \mathbf{t}\end{array}$} \\
\hline & 5 & 6 & 7 & 8 & & 5 & 6 & 7 & 8 \\
\hline 1 & 7 & 8 & 10 & 11 & 11 & 74 & 89 & 104 & 119 \\
\hline 2 & 14 & 16 & 19 & 22 & 12 & 81 & 97 & 113 & 129 \\
\hline 3 & 20 & 24 & 28 & 32 & 13 & 88 & 105 & 123 & 140 \\
\hline 4 & 27 & 32 & 38 & 43 & 14 & 94 & 113 & 132 & 151 \\
\hline 5 & 34 & 40 & 47 & 54 & 15 & 101 & 121 & 142 & 162 \\
\hline 6 & 40 & 48 & 57 & 65 & 16 & 108 & 129 & 151 & 172 \\
\hline 7 & 47 & 57 & 66 & 76 & 17 & 114 & 137 & 160 & 183 \\
\hline 8 & 54 & 65 & 76 & 86 & 18 & 121 & 146 & 170 & 194 \\
\hline 9 & 61 & 72 & 85 & 97 & 19 & 128 & 154 & 179 & 205 \\
\hline 10 & 67 & 81 & 94 & 108 & 20 & 135 & 162 & 189 & 216 \\
\hline
\end{tabular}

In the calculations, the seams of associated mining were not taken into account, but their capacity was added to the capacity of the considered seam.

\section{Conclusions}

It has been established that in some fields bedding of strata can be either concentrated or dispersed. Therefore, a group of seams concentration is introduced as a mixed bed. For the considered formations, the critical value of boundary stripping ratio is $5 \mathrm{~m}^{3} / \mathrm{t}$, in which the formations mainly belong to the category of dispersed or mixed bedding of strata and, therefore, the issue of the economic feasibility of applying for their development becomes relevant. For the category of dispersed bedded formations, consideration should be given to options for using the mining method for individual seams or groups of seams.

\section{References}

1. M. Tyulenev, O. Litvin, M. Cehlár, S. Zhironkin, M. Gasanov, Acta Montanistica Slovaca, 22:3, 296-302 (2017)

2. M. Tyulenev, O. Litvin, S. Zhironkin, M. Gasanov, Acta Montanistica Slovaca, 24:2, 8897 (2019) 
3. O. Litvin, M. Tyulenev, S. Zhironkin, S. Prokopenko, Acta Montanistica Slovaca, 22:2, 146-152 (2017)

4. M.A. Tyulenev, S.O. Markov, M.A. Gasanov, S.A. Zhironkin, Geotech. Geol. Eng., 36:5, 2789-2797 (2018)

5. A. V. Selyukov, Bulletin of the Tomsk Polytechnic University, Geo Assets Engineering, 326:12, 60-71 (2015)

6. A. V. Selukov, Taishan Academic Forum - Project on Mine Disaster Prevention and Control, 156-160 (2014)

7. A. Selyukov, V. Ermolaev, I. Kostinez, E3S Web Conf., 21, 01027 (2017)

8. Pavolová H., Khouri S., Cehlár M., Domaracká L., Puzder M. Metalurgija, 55:4, 712-714 (2016)

9. M. Tyulenev, S. Markov, M. Cehlar, S. Zhironkin, M. Gasanov, Acta Montanistica Slovaca, 23:4, 368-377 (2018) 